\title{
Pre-service Language Teachers' Cognitions about Language Learning/teaching and Cognition Refinements through a Reflection-oriented Practicum
}

\author{
Zohreh Shooshtari*, Kioumars Razavipur, Azimeh Takrimi
}

Shahid Chamran University of Ahvaz, Ahvaz, Iran

\begin{abstract}
Pre-service teacher cognition literature abounds with the concept of change as well as proposals regarding desirable conceptual changes to be undertaken so that teacher candidates can set out their path of professional development with right beliefs. Yet, such changes would seem less likely to occur if the trainees' thoughts, beliefs, and cognitions are not identified in the first place. This study was an attempt to identify the cognitions of EFL pre-service teachers and trace possible changes expressed by the candidates. Through a convenient sample of 64 pre-service teachers studying at three teacher training colleges in Iran, this mixed -methods exploration utilized a teacher cognition questionnaire and interview techniques. Results of the cognition questionnaire indicated that many of the candidates' cognitions were still in need of adjustments. Also, the content analysis of the interviews revealed that the candidates' attempts during the practicum revolved mostly around challenging debilitating beliefs, developing a sense of professional agency, managing stress, and resolving tensions between contradicting beliefs. Findings suggest that the trainees' prior experiences as language learners exerted a very influential effect on their cognitions and also their attempts to refine those cognitions.
\end{abstract}

Key words: Pre-service language teachers; Cognitions; Cognition refinements; ALACT model

\section{Article Information:}

Received: 9 August 2016 Revised: 2 January 2017 Accepted: 24 January 2017 Corresponding author: Department of English Language and literature, Shahid Chamran University, Ahvaz, Iran Email address: z.gshoodhtari@scu.ac.ir 


\section{Introduction}

Understanding the nature of belief/ cognition change is of utmost importance to the field of foreign language teacher education, particularly when pre-service candidates are concerned (e.g. Borg, 2015; Debreli, 2012; Mattheoudakis, 2007; Misrohmawati, 2016; Yuan \& Lee, 2014). While change can refer to many things including attitudes, knowledge, beliefs, and teaching practices, tracking conceptual change is far from easy in educational settings. Calderhead (1988b) acknowledges that learning to teach involves complex cognitive, affective and behavioral changes indicating that change can be multifaceted and difficult to trace. In this regard, teacher change studies are not scarce, and particularly, pre-service teacher change has attracted great attention in recent years. It is assumed that pre-service teachers' beliefs about language teaching have been shaped by their prior experiences as language learners and teacher training centers should be able to change and restructure those beliefs and produce 'teachers' out of those learners. On the basis of such arguments, different perspectives have been taken in viewing the situation either holistically or as separate parts.

One such perspective is that of the constructivists who pay considerable attention to the practicum as an instance of social settings in which teacher trainees can cognitively engage and do their apprenticeship; hence, they call it the Cognitive Apprenticeship (CA) Model (Collins, Brown, \& Newman, 1989). The specific type of practicum usually implemented in such a model tends to be of a reflective type, advocating the centrality of reflection in teachers' fulfilling their practicum.

Apparently, only recently has the field of English as a Foreign Language begun to realize that applying such models in language teacher education programs can both help explore the cognitive aspects of pre-service teachers' life and trigger belief changes for the best. Following Korthagen 
(1985- 2010), the ALACT model has been recently introduced in all preservice programs for English language teachers in Iran. The ALACT model formulates a cycle of steps in effective reflection including Action; Looking back at the action, Awareness of essential aspects, Creating alternative methods of action, and Trial of new practices. Given that in Iran, like many parts of the world, teachers with little training in teaching EFL may be pressed into service without adequate mental and cognitive preparation, this study seeks to address this challenge within this model of practice teaching that claims to provide a solution for such inadequacies. This study seeks to identify pre-service teachers' ways of knowing and the connection between what they know and what they do, a need which has been felt in the previous studies (Borg, 2015; Kumaravadivelu, 2008). In other words, this study was set up to explore EFL pre-service teachers' cognitions about language learning and teaching as well as to investigate the potential of this model in promoting belief refinements about language learning issues in an Iranian teacher education context.

\section{Review of the Related Literature}

2.1. Identification of beliefs and cognitions in pre-service teachers

In Zheng's (2009) view, teacher beliefs can be assumed as a set of conceptual representations which store general knowledge of objects, people and events, and their characteristic relationships. What Zheng puts forward after this definition is that beliefs are psychologically held understandings, premises, or propositions felt to be true. They are permeable and dynamic structures that act as a filter through which new knowledge and experience are screened for meaning. As the old adage says, pre -service candidates enter teacher training sites with pre-established beliefs which have been shaped through their schooling experiences (good or bad) as language learners. The cognitions and beliefs they bring with them have been 
researched with different intentions and purposes (e.g., Bailey et al., 1996; Brown \& McGannon, 1998; Farrell, 2001; Numrich, 1996; Tsang, 2004; Warford \& Reeves, 2003). Issues which have been examined mainly relate to the nature of the learning processes that teacher candidates experience and to the impact which pre-service teacher education programs have on what teachers know, believe, and do. In Borg (2015), a classification of major studies conducted in pre-service settings are reported focusing mainly on trainees' prior learning experiences and cognitions,trainees' beliefs about language teaching, trainees' decision-making, beliefs and knowledge during the practicum, and change in trainees' cognitions during teacher education. There, he highlights the strong links developed between the concerns of teacher educators and the focus of teacher cognition research. While all these studies share a concern for understanding the cognitions of pre-service language teachers, some, however, focus on capturing, describing, and classifying these cognitions and some on their development or change during teacher education.

\subsection{Cognitive change in pre-service language teachers}

Apart from those who persist in rejecting belief changes in teachers (e.g. Brown \& Cooney, 1982; Wilson, 1990), a good number of teacher cognition studies have been concerned with identifying the factors that stimulate preservice teachers' cognitive change as well as comparing exit cognitions to those with which they have entered the university. These studies, sometimes with mixed results, vary in what is considered to be evidence of cognition and cognitive change. They, however, shed light on a number of themes in the study of pre-service language teacher cognition. Misrohmawati (2016) reports cognitive development in three areas: material design, teaching methodology, and learning context. Yuan and Lee's (2014) findings show that student teachers' beliefs experienced different processes of change 
during the practicum, including confirmation, realization, disagreement, elaboration, integration, and modification. They believe, in order to facilitate the belief change process and promote student teachers' cognitive development, an open and supportive environment is needed to maximize their practice and learning during the teaching practicum. Cabaroglu and Roberts (2000) could trace belief developments in all but one of their twenty pre-service teachers. Grijalva and Barajas' (2013) findings demonstrated that students made links between theory and practice creating some changes in previous beliefs. Other studies (Peacock, 2010; Wong, 2010) attest to the stability of teacher cognition. In particular, beliefs about language aptitude, pronunciation, vocabulary acquisition, the benefits of practice, and an immersion approach to language learning appeared to remain stable (Wong, 2010)

\subsection{Pre-service teachers' beliefs/cognitions in the context of practicums}

As practicums are an inseparable part of many teacher education programs, a large number of studies in the context of pre-service EFL teachers have been conducted in practicum settings, oftentimes, with mixed, even contradictory results, however. Ong'ondo and Jwan (2009) reviewed literature on student teacher learning, collaboration, and supervision during the practicum. According to them, research covered such areas as student teachers' main concerns, student teachers' experiences, what and how student teachers learn and how specific innovations by particular universities contribute to teacher learning. They further conclude from the reviewed studies that with time, especially if the practicum session is extended (about one year) and if the student teachers were well supported (worked closely with their cooperating teachers and teacher educators), they were able to make quick progress from primary concern with survival to thinking about how they could facilitate learning among their own students. 
Tsang (2004) investigated how the student teachers' PPK (personal practical knowledge) influenced their decision making during their interactions with English language learners. Her analysis showed that 'during classroom teaching, the participants did not always refer to their personal practical knowledge' (p.194). Nevertheless, Tsang discovered that PPK featured during the student teachers' post-lesson discussions as they discussed how the lessons could be improved. She attributed this scenario which she termed a "delayed access to personal practical knowledge" to competition between several issues including circumstances of the classroom, thoughts on teaching, coursework at university and the PPK (as cited in Ong'ondo and Jwan,2009).

In a general teacher education practicum setting, participants in Turnbal's (2005) study were found to have the capacity to operate in their discursive consciousness, the ability to monitor their own actions and those of others, and to have observed tacit rules of behavior. Each student teacher demonstrated transformative capacity through engaging in action of her choice. Quite contrary to this, Mattheoudakis (2007) found that student teachers' engagement in the teaching practice seemed to have a low impact on the development of their beliefs.

Numrich (1996) studied diaries kept by 26 U.S. teachers during a practicum program. She found that pre-service teachers decided to promote or to avoid specific instructional strategies on the basis of their positive or negative experiences of these respective strategies as learners. They chose not to correct their students' errors simply out of their own recollections of past experiences of being overtly corrected by language teachers which had a prohibiting effect on their performance in the classroom. Also, Farrell (1999), admitting that student teachers' prior knowledge and personal understandings have an influential role in developing them as teachers, argues that in many countries around the world, the method of teaching 
English has changed over the years from an emphasis on overt grammar instruction in the past to a more communicative approach in recent times. He adds:

However, many pre-service teachers have been educated in English by traditional methods of drill and memorization of grammar rules. So there can be a mismatch between what the students have learned in the past and what they are presented in the teacher education program. An important question then arises as to how these prior experiences, often tacit, can be made more conscious and integrated into the curriculum (Farrell, 1999: 1).

One of the major findings Numrich (1996) reported about her findings was that trainees were frustrated with their teaching, i.e., ' $[\mathrm{M}]$ managing class time; [G]giving clear directions [R]responding to students' various needs [T]teaching grammar effectively [A] assessing students' learning [F]focusing on students rather than on self' (p.134). Arguing that some of these concerns were not resolved by the end of the program, she stresses, the most difficult part of teaching for this group of teachers was time management. By the end of the 10-week period, at least half of the teachers mentioned in either their diaries or analyses that they still did not have confidence in managing time... many of them felt unsettled about how to balance teacher-centered activities with student-centered activities (p.142).

Moreover, she believes that the feeling of being pulled between wanting to try out ideas that were presented in the practicum and giving their students what they most needed was part of the teachers' frustrations about whether or not they could meet the needs of their students.

\subsection{Research questions}

Following Shulman (1987) who believes the development from students to teachers, from a state of expertise as learners through a novitiate as teachers 
highlights the complex bodies of knowledge and skills needed to function effectively as a teacher, and Korthagen (1985-2010) who strongly believes that this development can be fully captured through reflection-oriented activities, this study attempts to explore pre-service EFL teachers' beliefs and cognitions. It also attempts to explore how these candidates think and change beliefs about language learning issues, themselves and their own process of teacher development. It, therefore, addresses the following questions:

1. What beliefs and cognitions do pre-service language teachers have about learning and teaching languages?

2. How are these beliefs and cognitions refined in the process of the reflective practicum?

\section{Method}

\subsection{Participants and context of the study}

A four-year pre-service EFL teacher education program at Farhangian University was chosen for this investigation because this university is considered the main springboard for those interested in teaching English in secondary schools in Iran. According to university curriculum, student teachers are provided with language teaching courses in the first two years and undertake their practicums in the next four subsequent semesters, along with the remaining linguistics and methods courses. Sixty-four pre-service trainees (28 females, 36 males), aged between 21 and 25, participated in this study, as a convenient sample. These candidates were studying at different branches of the university, located in Ahvaz, Tehran, and Shiraz (three provincial capitals in Iran). Based on the availability criterion, thirteen of these trainees were closely observed while implementing the ALACT stages. The aim was to reach at an in-depth understanding of their 
experience of the reflective practicum and trace changes in their beliefs and cognitions. To follow these stages, candidates were assigned practice teachings to do at school (the Action phase). Having filmed these teaching practices, candidates were required to watch them, reflect on them, and write reflective notes on how they found their job (the Looking-back phase). Completing these reflective activities would throw them into the next phase, discovering essential aspects of what they had done at school (the Awareness phase). This individual reflection was completed by collective reflection in roundtable discussions held at the campus the day after, which comprised the third phase (the Creative alternative phase). Based on received modifications at roundtable discussions, candidates could plan possible redo lessons (the Trial phase), which could mean the practice had come full circle.

\subsection{Instruments}

To capture teachers' current cognitions, a cognition questionnaire was administered to all the participants. In the next phase, the 13 candidates available for observation were assigned to small groups of three or four. They were then given the chance to teach in increasing lengths (from 10 to 60 minutes) while being video-recorded. Further, they were invited to reflect upon their teaching, to attend roundtable discussions and to prepare freewrites (reflective notes written by the participants after each practicum through the whole semester). Next, the stimulated recall interviews were run, audio-recorded, transcribed, and subjected to content analysis. These students needed to fulfill at least six practice teaching tasks, which could sometimes double, concerning the fourth and the fifth phases of the ALACT model (Creating alternative methods of action and Trial). These tasks required them to redo the practicums after reflection tasks and attending roundtable discussions during which they received modifications in plan and 
procedure both from their educator and peers. Carrying out these practicums took up the whole semester (16 weeks) during which the student teachers did and filmed their teaching tasks on Tuesdays and met for roundtables on Wednesdays. After these tasks were done, the stimulated-recall interviews were administered, so as to elicit verbal responses about the participants' emotional and cognitive involvement in their teaching.

\subsubsection{The cognition questionnaire}

Since these EFL teacher candidates were still in the process of learning English, and learning how to teach English simultaneously could alter the situation substantively, an instrument was sought that could integrate both foreign language learning and teaching issues. Consequently, using a literature search, a 42-item Likert-type questionnaire based on Horwitz's Inventory on beliefs (1988) and statements from Lightbown and Spada (2006) was devised that could measure beliefs about both issues. Six questions were taken from the BALLI and 18 items were adapted from Lightbown and Spada's. The remaining 18 items were adapted and developed by the researcher based on the literature, context, and the research needs. To obtain evidence for the reliability and validity of the questionnaire, it was first pilot-tested on a separate sample of $60 \mathrm{EFL}$ practicing teachers (predominantly females with teaching experience between 1 and 28 years) serving at different cities of Khuzestan province. The participants who were attending a local workshop were asked to respond to the items on a 5-point rating scale, from strongly agree (1), to strongly disagree (5). The estimated reliability by Cronbach's alpha was found to be 0.73 . Preliminary evidence relating to the concurrent validity of the questionnaire was secured by correlating the questionnaire with the Beliefs About Language Learning Inventory (BALLI, Horwitz, 1988) administered to the same participants. The BALLI, with its 34 items, 
measures learners' beliefs about language learning areas such as aptitude, strategies, and motivation on a 5-point Likert scale. The Pearson correlation coefficient was found to be $r=0.45, \mathrm{p}<0.001$. Having piloted the cognition questionnaire (see Appendix), the researchers administered it to all preservice teachers $(N=64)$ taking part in the study.

\subsubsection{Reflective notes and field notes on observations}

Post-teaching reflective activities assigned to student teachers were based on the video recordings they had provided on their teaching practices. According to the procedure, upon doing their practicums in schools, reflective writings were assigned to them to be done both in private and in class. First, they were required to watch their films at home/dorm, reflect upon them the night after each practicum session was over and write reflective notes. These notes (in their L1), which were used as a data gathering tool, enabled the researchers to arrive at a deeper understanding of how pre-service teachers were experiencing their learning about how to teach English. They revolved mostly around main questions proposed by Korthagen, Kessels, Koster, Lagerwerf, and Wubbels (2001) about various aspects of the situation touching upon the dimensions of wanting, feeling, thinking and doing, promoting concreteness in the reflective process (e.g., How did you feel this week? What did you want? What did the students want?).

As the next step, the participants were inquired about their practice at school in roundtable discussions held at the university campus the following day. During these inquiries, they were free to play/pause their own or peers' videotaped lessons, discuss critical moments and share ideas about background reasons or alternatives for their actions. At the end of these individual and group reflections and roundtable sessions, they were given time to jot down their final comments on their own or others' teaching. 
These notes were collected and used as data and as supports for the codes and themes extracted from the contents. Their teacher educator, also, one of the authors of the present study, managed the whole procedure including groupings, observations, roundtable discussions, and provision of feedback/assignments.

Finally, field notes were taken at different stages of observation, reviewing the videos and other data gathering steps. These were filed as 'field notes' and were content analyzed for codes and themes along with candidates' reflective notes. All these roundtable discussions were audiorecorded and scrutinized to both triangulate the data and lend credibility to interpretations and inferences obtained through the interviews. These themes were checked against the areas of cognition identified through the cognition questionnaire discussed above.

\subsubsection{Stimulated- recall Interviews}

Interviews based on the analysis of video-recorded practices (Borg, 2015) have been widely cited in teacher cognition studies. This qualitative phase of the study was conducted one or two days after each practicum session. Using the prompts obtained from the reflective notes and field notes, candidates were inquired about their teaching experience through having them recall and/or play their videos. Responses were audio-taped, transcribed, and content-analyzed too. Utilizing the NVivo software, a computer program that facilitates the qualitative analysis of transcribed texts (version 10), these content analyses were run, along with manual counting of codes and themes by the researchers as a control for computerized analyses. Also, to enhance the trustworthiness of the findings, the obtained themes were checked by an expert in the field of ELT and another one in the field of content analysis, to reach "intercoder or crosschecking agreement" (Creswell, 2009). 
In this study, we focused on "change" in pre-service teachers' cognitions/beliefs, working at an individual level of analysis. Analysis of interview and freewrites contents was based on Creswell's (2009) six steps including organizing, reading for a general sense, coding the chunks or segments, describing in the form of themes and categories, discussing through interconnecting themes and subthemes and representing them in tables, and interpreting the meanings.

\section{Results}

\subsection{Findings from the cognition questionnaire}

In the quantitative phase of data analysis, this study utilized mainly descriptive statistics (frequency counts and percentages) to identify commonly held beliefs among the participants. Table 1 presents a summary of the participants' cognitions/beliefs as identified in the Cognition Questionnaire. 
Table 1

Summary of the most agreed/disagreed upon items in the cognition questionnaire

Item 5 It is easic
language.

8 You shouldn't say anything in your second language until you can say it correctly.

18 Practice makes perfect.

21 Motivation is a major predictor of success in language learning.

26 Teachers should teach simple language structures before complex ones.

33 The teacher should be an expert at language teaching.

35 The teacher should be an expert at showing students how to learn languages.

40 The learner should try and use L2 as much as possible inside the classroom.

42 People learn languages in the same way.

\section{$\underline{\mathbf{n}(\%)}$}

agree undecided disagree

$56(88) \quad 4(6)$

6(9) $\quad 7(11) \quad 51(80)$

57(89) $\quad 6(9) \quad 1(1)$

60(94) 3(5) 1(1)

$56(88) \quad 5(8) \quad 3(5)$

60(94) 3(5) 1(1)

54(84) $7(11) \quad 3(5)$

56(87) $7(11) \quad 1(1)$

$8(12) \quad 5(8) \quad 51(80)$

Note. Agree $=$ collapsed scores for Strongly Agree and Agree; $\mathrm{U}=$ Undecided; Disagree = collapsed scores for Strongly Disagree and Disagree 
Among all the 42 items, 9 items had attracted marked dis/agreement from the candidates. As can be inferred from the Table, the criterion for deciding extreme dis/agreement was set to be 50. In other words, only those items with frequencies above 50 are reported here. Also, for ease of viewing, ratings were collapsed into three categories namely agree (for strongly agree and agree), undecided and disagree (for disagree and strongly disagree).

As Table 1 indicates, items 21 and 33 as well as items 18, 5, 26, 40 and 35 are most likely to be agreed by the candidates. Candidates are very much likely to believe that motivation plays an important role in language learning and that a language teacher should be an expert $(n=60,94 \%)$. In other items, this condition is not borne out and few candidates show agreement towards the deep-rooted beliefs that practice makes perfect or it is easier for children than adults to learn a foreign language. These pre-service teachers put equal weight on items 26 and 40 saying that difficulty level should be a concern when presenting structural items (item 26), and that learners should attempt to use as much foreign language as they can inside class (item 40). Also, $84 \%$ of the candidates believed that a language teacher should be able to show learners how to learn the language (item 35).

The participants expressed strong opposition to the idea that learners should use a language item only if they know how to use it correctly (item 8, 80\%). Equal disagreement was expressed about the far-fetched idea that people learn languages in the same way. Of these nine prevailing beliefs, however, six items seem to be learner-oriented and only three are teacheroriented. 


\subsection{Major areas of change}

Aside from major cognition areas identified in the participants' responses to the questionnaire, further analyses were done to spot critical moments of development or belief refinement processes reflected in candidates' interviews and writings, a point addressed by the second research question. Through the process of coding and condensing the data, major themes and subthemes flourished with references which could evidence the process of cognition change in these candidates. Four such themes are reported in this article (See Table 2) along with references which can illustrate belief changes in these candidates experiencing the ALACT-based reflective practicum.

Presumably, the structured reflection facilitated by this model coupled with video shots tends to act like a catalyst making reflection flow more smoothly and tangibly among the participants as being both interpersonal and intrapersonal. This idea is endorsed by the many references they make to the ability they are afforded through the use of the ALACT and videorecording.

\subsubsection{Challenging debilitating beliefs}

The first and foremost sign of development in this regard is the way they cope with their debilitating beliefs making use of own reviewing and reflecting activities or peers' commenting on them. Many of such debilitating beliefs originate from their prior experiences as teenage language learners. As shown in Table 2, many notes refer back to the feelings they might have felt in reaction to their teachers' implementing notvery-effective methods in language classes (e.g., School class is for learning about language; good teachers correct all students' mistakes; or vocabulary and grammar knowledge are the most important features of language teachers). 


\subsubsection{Developing a sense of professional agency}

These candidates are presumably faced with a multi-faceted task of learning the language, learning how to teach the language, learning how to evaluate own and peers' teaching practices, and how to distinguish a fit between the learners' needs and the education they offer to them. They tend to be in constant forward and backward moves between the way they have been taught and the wad they are required to teach in their practicum programs. Deciding is not an easy undertaking given that their own level of language proficiency does not allow them to take risks and initiate activities against their formal learnings. Watching videos of their own or peers' practices is probably the best chance for them to see, for instance, what 'a teacher standing in front, holding his book all the time' can look like, or 'the way a teacher can confuse his students by providing unnecessary information when explaining a new word?' This group of subthemes indicate that the candidates are in the way of developing a sense of agency whereupon they can judge the requirements of their future profession, hence, a sense of professional agency.

\subsubsection{Managing stress reduction techniques}

The most prevalent theme in the participants' notes as well as researchers' field notes pertains to the benefit of the practicum program in reducing their stress. They expressed concern and anxiety about many aspects of the language classroom including class management, learners' superior language abilities, maintaining friendship, even the arrangement of the seats (See Table 2).

Doing my practicum, I'm so busy controlling the class that I miss my plan. I guess controlling the class is the most important thing because it helps the teacher to have an organized teaching. I think I'm unable to 
control the whole class. Many times I miss the back seats and this makes me lose my confidence and I can't focus on my teaching (S11).

\subsubsection{Realizing and resolving tensions}

As shown in Table 2, the references under this theme point to the participants' attempts to resolve the conflicts existing between the mentors' and the teachers' leads, which can reflect discrepancies between the guidelines suggested by the older and the more recent approaches towards language teaching. Taken as hands-on experiences, these teaching practices are the first experimentation sites for the candidates to put their theories into practice and watch what is practical and what is impractical. They are finding their own way, realizing that "each class has its own requirements" (S 3), or that "I'm sure now CLT principles should be tailored to students' needs" (S7). Their expressed concern for the tension between teaching grammar explicitly and either not teaching grammar or teaching it implicitly is recurrent in their reflective notes. So is their worry for handling misbehavior or destructive students which can remain unresolved if proper hints are not provided to them either from within or from without. 
Table 2

\section{Summary of change areas in pre-service teachers' cognitions about} language learning/teaching

\section{A priori beliefs/cognitions}

1 Challenging debilitating beliefs

School teachers can't do much about
sts' speaking. School class is for
learning about language.

A posteriori beliefs/cognitions

I'm happy today because I used simple English in class all the time; I spoke slowly and they were following me carefully. Both the students and I were really enjoying. I wasn't sure I could do that.

Sts are sometimes too tired to learn When teachers see sts' boredom, they shouldn't keep finishing the lesson.

I introduced some games today and despite the break, they insisted on staying and finishing. I understood that when having fun, any minute can be a point of learning. me for they will use it against me and make class a mess.

I thought good teachers correct all sts' mistakes. My own school teachers did that.

I thought just by vocabulary and grammar knowledge, you can teach English easily.
Now I understand that teacher's authority is hidden in friendly relationships with sts. Even a noisy class can be yours. I'm not afraid of noisy classes anymore because interaction comes out of such situations.

Sometimes just exposing them to language works. Today, I just let them listen to correct pronunciations. So effective!

More skills are involved than mere knowledge of language: questioning, discourse, tone of 
Developing a

sense of

professional agency
I started teaching like my teachers, explaining everything in L1.

In my video, I was standing in front, holding my book in my hand all the time.

Today's negative point was that I wasn't focused enough, so I confused sts with my multiple examples, trying to explain all the meanings of the word 'media', its singular and plural forms, etc.

I thought I needed to do my best to make them pronounce all the letters and sounds clearly. voice. Watching my video, I saw their importance which I wasn't aware of before.

I didn't like my video that way, if I want to do differently, I need to improve my English and use less L1.

In the redo session, I tried to come out of my safe zone, walk and move around the seats, like a real teacher.

Sts don't need to know all the aspects of new vocabularies. I should stick to those present in their lesson first and work on peripherals as needed or asked by sts.

I saw today there is no need to make them pronounce all the individual sounds or name letters. Sts communicated with me even with mispronunciations; we all enjoyed. Now I can plan tasks to help them practice at home instead of wasting class time over correcting mispronunciations.

Today, I asked one of them to read out the text to class with her 'good' accent, giving me time to model her for the class and confidence to elaborate on her 
utterances, showing them I had many things to offer, despite my bad pronunciation.

My biggest problem was stress. My heartbeat didn't let me think or hear sts well. I thought they were noticing my stress too.

4 Realizing and resolving tensions
We can't decide between the mentor's and teacher's recommendations, living in different worlds. What mentor says is inapplicable and what teacher wants is unscientific.

I couldn't imagine an English class without explicit grammar; all my English study was but grammar and vocabulary.

How to behave towards destructive sts has always been my concern. Our own teachers would only punish or, at best, ignore them.
Watching my videos and following roundtable discussions helped me do things to reduce stress: improving my knowledge, learning questioning/ answering and other elicitation techniques, articulating my thoughts in recall interviews, finding my strengths and trying to implement them more in my next practicums.

Each class needs its own requirements. I liked to speak English in class as suggested by CLT and the teacher disagreed because she thought sts wouldn't understand. I spoke slowly in simple English, using lots of pantomime, gesture, and body language; it worked.

After the discussions, we concluded that excluding grammar explanations was unwise, and giving/ eliciting real life examples was more effective. I'm sure now CLT principles should be tailored to sts' needs.

Watching my classmate's video taught me how to resolve this. One st made a catlike sound. She stopped, looking through the class, speculating where the sound came from. Taking an on-line decision, 
she asked the student to stand up and read the whole passage with that catlike sound. Wonderful! Sts don't need punishment, they need to be properly managed.

\section{Discussion}

This investigation was an attempt to uncover the beliefs and cognitions of pre-service language teachers during their practicum procedure in an Iranian context. It also aimed at identifying trainees' change areas while carrying out these hands-on experiences. Major themes emerging from the cognition questionnaire point to candidates' discovery of the incompatibility of topdown theories and methods advocated by language teacher trainers and the actual classroom life (See Kumaravadivelu, 2008). Moreover, student teachers were found to hold a number of conceptions about language learning and teaching which are at odds with SLA research findings. For instance, they held that learning a foreign language is easier for children than for adults, or that practice makes perfect, or that apparently simple structures should be presented before those that seem more complicated. These behaviorally-oriented cognitions or 'urarticulated and simplified' belief(s) as Pajares (1992, p. 322) stresses, are characteristic of those resistant-to-change educational beliefs that pre-service teachers bring to teacher preparation programs. Other beliefs held by the majority of the candidates also indicated that these candidates seemed to be still leaning on behavioristic approaches rather than communicative guidelines, despite the CLT trend widespread in their methods classes. This endorses what Lortie (1975) and other advocates of the influence of past experience put forward (Borg, 2015; Urmston, 2003; Warford \& Reeves, 2003). Farrell (2007) believes that pre-service teachers may not be aware of the influence of their experience as students on their teaching. Support for this idea comes from 
different references these candidates make to the way they have been taught, mostly in Grammar Translation method. "The way I have been taught English was through Farsi (our L1). Our English teachers explained everything including grammar in Farsi and I can't forget that and start my own. I know if I want to teach grammar in context without explicit explanations, regarding my students' language level, it is impossible to do that all in English" (S4, in roundtable2).

There was a convergence between findings of the cognition questionnaire and the qualitative data on the areas of change identified in the transcripts. For instance, candidates' predominant disagreement over item 8 which forbids language users' use of incorrect language until they have mastered the language point, is in line with the comment that says, "I saw today there is no need to make them pronounce all the individual sounds or name letters. Students communicated with me even with mispronunciations; we all enjoyed" (See table 2).

On the other hand, their shared agreement about the necessity of L2 use inside the classroom by the learners is reflected in their many instances of expressed desire for learners' use of the language either to communicate or to understand the teacher. The discovery one participant reports says, "I'm happy today because I used simple English in class all the time; I spoke slowly and they were following me carefully".

Through these activities, candidates could possibly find opportunities to challenge debilitating beliefs, realize and try to resolve tensions, and practice stress reduction techniques with the help of the group, hence fostering the social nature of learning. Turnbull (2005) argues that, 'if teachers are expected to be active agents in their profession, the development of professional agency in student teachers as beginning professionals is essential' (p. 195). One area in which the candidates in this study conceived a change as a result of experiencing the ALACT model was 
their increased ability to cope with stress. What seems to contribute to their better coping strategies is sharing their videos, recounting their feelings through the teaching experience, planning redo sessions, and finding time to reflect critically both collectively and individually. Not surprisingly, roundtable sessions were the most liked element of the project and were perceived as "very enjoyable and instructive".

While this change/development seems inconsistent with studies suggesting that student teachers' beliefs are "inflexible" (e.g. Mattheoudakis, 2007; Peacock, 2001; Tabachnick \& Zeichner, 2003; Wong, 2010), the findings of this study are consistent with studies confirming that these beliefs are variably permeable to change (Brandenburg, 2008; Cabaroglu \& Roberts, 2000; Calderhead \& Robson, 1991; Cheng, Cheng, \& Tang, 2010; Misrohmawati, 2016) in different individuals. In such development processes, the role of the associate teacher and mentor and teacher training program in providing cognitive support and guidance should not be overlooked. What student teachers need is someone who has them face their fears and tensions and through scaffolding guides them to think critically about their own actions. Cabaroglu and Roberts (2000) argue that taking 'program as variable' suggests that training activities should take into account the variable, cumulative and evolutionary nature of student teacher belief development and that early confrontation of pre-existing beliefs can contribute to subsequent development. Similar to our findings, candidates in Farrell's (1999) study discovered that reflecting on their prior experiences of learning and actual experience of teaching constituted a powerful method of shaping their own development as teachers. Moreover, like pre-service teachers in Brandenburg (2008), the reflective assignments and free writes seemed to make this confrontation easier for candidates taking part in this study, making them more aware of their past experiences and the changes they needed to develop to become effective teachers. 


\section{Conclusion}

The findings of this study indicate that change, not as an 'all-or-nothing' but as a gradual, cumulative and dynamic phenomenon, develops in different individuals. Findings revealed that the type of experience pre-service students bring with them can have a lingering effect on what they absorb from theories exposed to them in teacher education programs and if they find opportunities to put those theories and prior beliefs into practice, they will explore their effectiveness, which might, in turn, culminate in cognition changes. The cognitions and change processes highlighted in this study, though very helpful for teacher education planners, may not represent preservice teachers' cognitions in other contexts due to the fact that these nonnative, non-proficient candidates may hold different beliefs originating from different learning contexts. Finally, further studies are needed to uncover the factors contributing to or impeding such cognition developments.

\section{References}

Bailey, K. M., Bergthold, B., Braunstein, B., Jagodzinski Fleischman, N., Holbrook, M. P., Tuman, J., Waissbluth, X., \& Zambo, L. J. (1996). The language learners' autobiography: Examining the 'apprenticeship of observation'. In D. Freeman and J. C. Richards (Eds.), Teacher Learning in Language Teaching (pp. 11-29). New York: Cambridge University Press.

Borg, S. (2015). Teacher cognition and language education: Research and practice. London: Bloomsbury.

Brandenburg, R. (2008). Powerful pedagogy: Self-Study of a teacher educator's practice. VIC, Australia: Springer. 
Brown, C. A., \& Cooney, T. J. (1982). Research on teacher education: A philosophical orientation. Journal of Research and Development in Education, 15(4), 13-18.

Brown, J. and McGannon, J. (1998). What do I know about language learning? The story of the beginning teacher. 23rd ALAA Congress. Retrieved from http://www.cltr.uq.edu.au/alsaa/ proceed/bro-mcgan.html.

Cabaroglu, N., \& Roberts, J. (2000). Development in student teachers' preexisting beliefs during a 1-year PGCE program. System, 28, 387-402.

Calderhead, J. (1988b). Introduction. In J., Calderhead (Ed.), Teachers' professional learning. London: The Falmer Press.

Calderhead, J., \& Robson, M. (1991). Images of teaching: student teachers' early conceptions of classroom practice. Teaching and Teacher Education, 7(1), 1-8.

Cheng, M. M.H., Cheng, A. Y.N., \& Tang. S. Y.F. (2010). Closing the gap between the theory and practice of teaching: Implications for teacher education programmes in Hong Kong, Journal of Education for Teaching, 36(1), 91-104.

Collins, A., Brown, J. S., \& Newman, S. E. (1989). Cognitive apprenticeship: Teaching the crafts of reading, writing, and mathematics. In L.B. Resnick (Ed.). Knowing, learning, and instruction: Essays in honor of Robert Glaser (pp.453-494). Hillsdale, NJ: Erlbaum.

Creswell, J. W. (2009). Research design: Qualitative, quantitative, and mixed methods approaches $\left(3^{\text {rd }}\right.$ Ed.). Thousand Oaks, CA: Sage.

Debreli, E. (2012). Change in beliefs of pre-service teachers about teaching and learning English as a foreign language throughout an undergraduate pre-service teacher training program. Procedia-Social and Behavioral Sciences, 46, 367-373.

Farrell, T. S. C. (1999). The reflective assignment: Unlocking pre-service teachers' beliefs on grammar teaching. RELC Journal, 30, 1-17. 
Farrell, T. S. C. (2001). English language teacher socialization during the practicum. Prospect, 16, 49-62.

Farrell, T. S. C. (2007). Failing the practicum: Narrowing the gap between expectations and reality with reflective practice. TESOL Quarterly, 41(1), 193- 201.

Freeman, D., \& Richards, J. C. (1996). Teacher learning in language teaching. Cambridge University Press.

Golombek, P. R. (1998). A study of language teachers' personal practical knowledge. TESOL Quarterly, 32(3), 447-464.

Golombek, P. R. (1998). A study of language teachers' personal practical knowledge. TESOL Quarterly, 32(3), 447-464.

Grijalva, Sofía D. C., \& Barajas, E.R.E. (2013). Pre-service teachers' beliefs about language teaching and learning: A longitudinal study. PROFILE, 15 (1), 81-96.

Horwitz, E.K. (1988). The beliefs about language learning of beginning university foreign language students. The Modern Language Journal, 72(3), 283-294.

Korthagen, F. A. J. (1985). Reflective teaching and preservice teacher education in the Netherlands. Journal of Teacher Education, 36(5), 1115.

Korthagen, F. A. J., Kessels, J., Koster, B., Lagerwerf, B., \& Wubbels, T. (2001). Linking practiceand theory: The pedagogy of realistic teacher education. Mahwah, NJ: Erlbaum.

Korthagen, F. A. J. (2010). Situated learning theory and the pedagogy of teacher education: Towards an integrative view of teacher behavior and teacher learning. Teaching and teacher education, 26(1), 98-106.

Korthagen, F. A. J., \& Vasalos, A. (2005). Levels in reflection: core reflection as a means to enhance professional growth. Teachers and Teaching: Theory and practice, 11(1), 47-7?. 
Kumaravadivelu, B. (2008). Cultural globalization and language education. New Haven, CT: Yale University Press.

Lightbown, P. M., \& Spada, N. (2006). How languages are learned.

Oxford: Oxford University Press.

Lortie, D. C. (1975). School teacher: A sociological study. Chicago: University of Chicago Press.

Mattheoudakis, M. (2007). Tracking changes in pre-service EFL teacher beliefs in Greece: A longitudinal study. Teaching and Teacher Education, 23, 1272- 1288.

Misrohmawati, E. R.R. (2016). "What makes you different?": The process of teacher cognitive development in pre-service EFL teacher education. Proceeding of International Conference on Teacher Training and Education, 1(1), 145-149. http:// jurnal. fkip. uns.ac .id/index. php/ ictte/ article/view/7567.

Numrich, C. (1996). On becoming a language teacher: Insights from diary studies. TESOL Quarterly, 30, 131-53.

Pajares, M. F. (1992). Teachers' Beliefs and Educational Research: Cleaning Up a Messy Construct. Review of Educational Research, 62 (3). 307-332.

Peacock, M. (2001). Pre-service ESL teachers' beliefs about second language learning: A longitudinal study. System, 29(2), 177-195.

Shulman, L.S. (1987). Knowledge and teaching: foundations for the new reform. Harvard Educational Review, 57(1), 1-21.

Tabachnick, R. B., \& Zeichner, K. M. (Ed.) (2003), “Teachers' beliefs and classroom behaviors: Some responses to inconsistency", In M. Kompf \& P. M. Denicolo (Eds.), Teacher thinking twenty years on: Revisiting persisting problems and advances in education, Lisse, the Netherlands: Swets and Zeitlinger, pp. 165-175.

Tsang, W. K. (2004). Teachers' personal practical knowledge and interactive decisions. Language Teaching Research, 8, 163-98. 
Turnbull, M. (2005). Student teacher professional agency in the practicum. Asia-Pacific Journal of Teacher Education, 33 (2), 195-208.

Urmston, A. (2003). Learning to teach English in Hong Kong: The opinions of teachers in training. Language and Education, 17, 112-37.

Warford, M. K. and Reeves, J. (2003). Falling into it: Novice TESOL teacher thinking. Teachers and Teaching, 9, 47-66.

Wilson, S. M. (1990). The secret garden of teacher education. Phi Delta Kappan, 72, 204-209.

Wong, M. S. (2010). Beliefs about language learning: A study of Malaysian pre-service teachers. RELC Journal, 41(2), 123-136.

Yuan, R., \& Lee, I. (2014). Pre-service teachers' changing beliefs in the teaching practicum: Three cases in an EFL context. System 44, 1-12.

Zheng, Hongying (2009). A review of research on EFL pre-service teachers' beliefs and practices. Journal of Cambridge Studies, 4(1). 73-81. 


\section{Appendix}

\section{Foreign Language cognitions questionnaire}

This questionnaire has been developed to serve as a tool for helping student/teachers explore their own cognitions concerning foreign language learning and teaching. Read the statements below and then tick one choice: 1) strongly agree, 2) agree, 3) undecided, 4) disagree, 5) strongly disagree. There are no right or wrong answers.

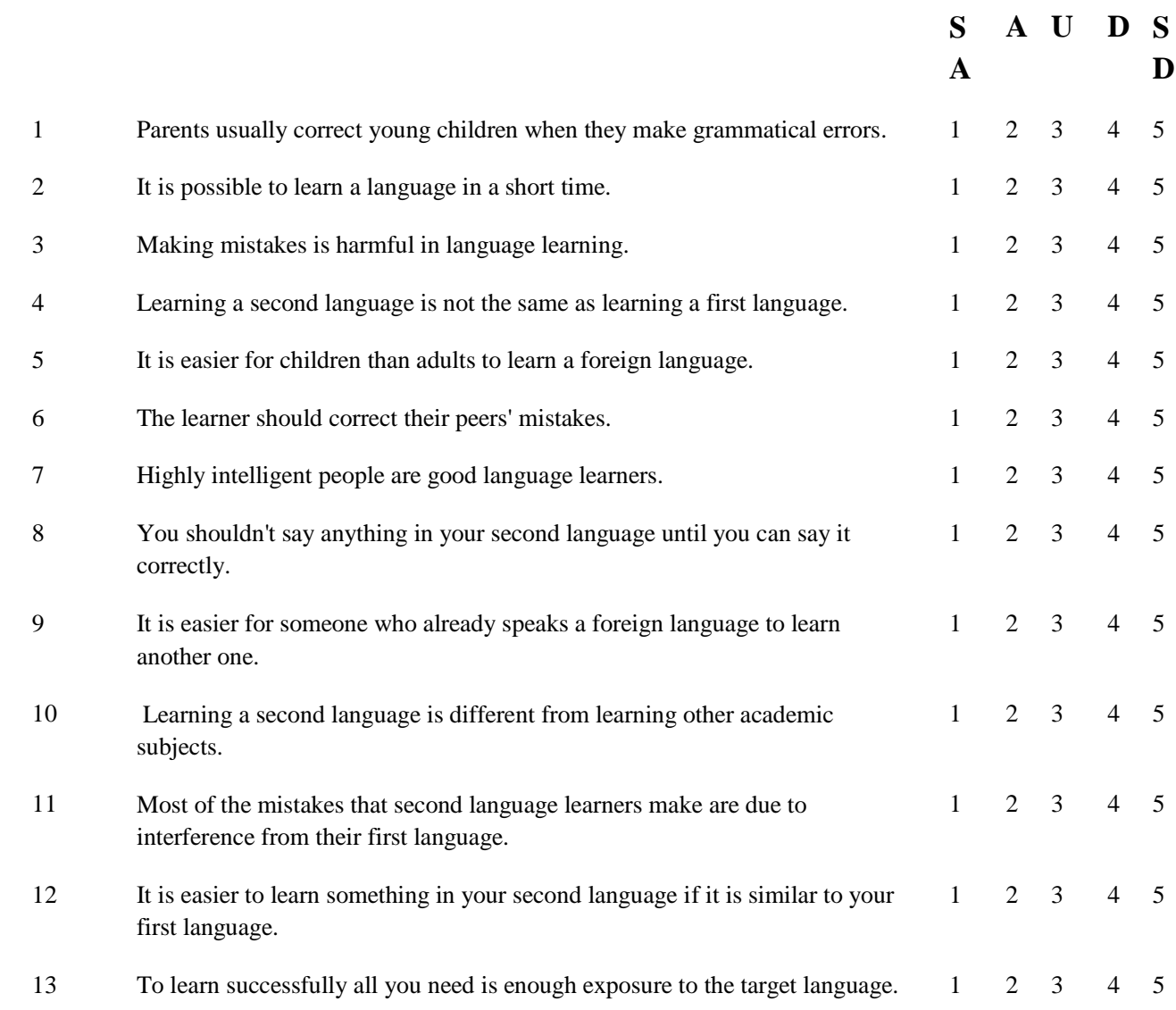


15 Foreign language learners should only use patterns they have been taught.

16 Once learners know 1000 words and the basic structure of a language, they can easily participate in conversations with native speakers.

17 When learners are allowed to interact freely (for example, in group or pair activities), they copy each other's mistakes.

18 Practice makes perfect.

19 It is important to speak English with an excellent pronunciation.

20 Languages are learned through imitation.

21 Motivation is an important factor in language learning.

22 Mistakes by foreign language learners are due to their lack of knowledge.

23 It is necessary to know about English-speaking cultures in order to speak English.

Students can learn both language and academic content (for example, science and history)simultaneously in classes where the subject matter is taught in their second language.

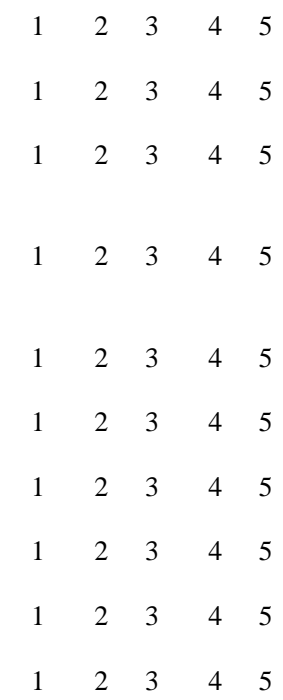

$\begin{array}{lllll}1 & 2 & 3 & 4 & 5\end{array}$

$\begin{array}{lllll}1 & 2 & 3 & 4 & 5\end{array}$
Grammatical rules should be presented one at a time.

Simple structures should be presented before more complex ones.

27

The earlier a second language is introduced in school programs, the greater the likelihood of success in learning.

$\begin{array}{lllll}1 & 2 & 3 & 4 & 5\end{array}$

$\begin{array}{lllll}1 & 2 & 3 & 4 & 5\end{array}$

$\begin{array}{lllll}1 & 2 & 3 & 4 & 5\end{array}$

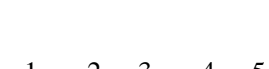

Learners' errors should be corrected by the teacher immediately to prevent the $\begin{array}{lllllll}1 & 2 & 3 & 4 & 5\end{array}$ formation of bad habits.

29 Teachers shouldn't use materials that expose students to structures they

$\begin{array}{lllll}1 & 2 & 3 & 4 & 5\end{array}$ haven't been taught yet.

$30 \quad$ The most important part of learning a foreign language is learning grammar.

31 Students learn what they are taught.

32 Teachers should rephrase learners' errors rather than focusing on the mistake.

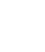

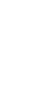

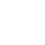


34

36

37

38

38

39

40

41

42
The teacher should be an expert at learning languages.

The teacher should be an expert at showing students how to learn languages.

The teacher should be a native speaker.

Classrooms are good places to learn about language but not for learning how to use language.

The teacher should only use the student's L2 when teaching.

It is important for learners to be able to pronounce all the individual sounds in the second language.

The learner should try and use L2 as much as possible inside the classroom.

The learner should correct their own mistakes.

People learn languages in the same way.

$\begin{array}{lllll}1 & 2 & 3 & 4 & 5 \\ 1 & 2 & 3 & 4 & 5 \\ 1 & 2 & 3 & 4 & 5 \\ 1 & 2 & 3 & 4 & 5 \\ & & & & \\ 1 & 2 & 3 & 4 & 5 \\ 1 & 2 & 3 & 4 & 5 \\ & & & & \\ 1 & 2 & 3 & 4 & 5 \\ 1 & 2 & 3 & 4 & 5 \\ 1 & 2 & 3 & 4 & 5\end{array}$


Notes on Contributors:

Zohreh Shooshtari is an assistant professor of Applied Linguistics at the department of English language and Literature of Shahid Chamran university of Ahvaz, Iran. Her areas of research interest include instructed second language acquisition, academic writing, the role of feedback, and learning transfer. She has presented and published nationally and internationally on issues related to her research interest.

Kioumars Razavipour is an assistant professor of Applied Linguistics at the department of English language and Literature of Shahid Chamran university of Ahvaz, Iran. His areas of research interest include second language acquisition and language testing. He has presented and published nationally and internationally on issues related to his main research interest.

Azimeh Takrimi is a PhD student of TEFL at the department of English language and Literature of Shahid Chamran university of Ahvaz, Iran. Her areas of research interest include instructed second language acquisition and teacher education. 